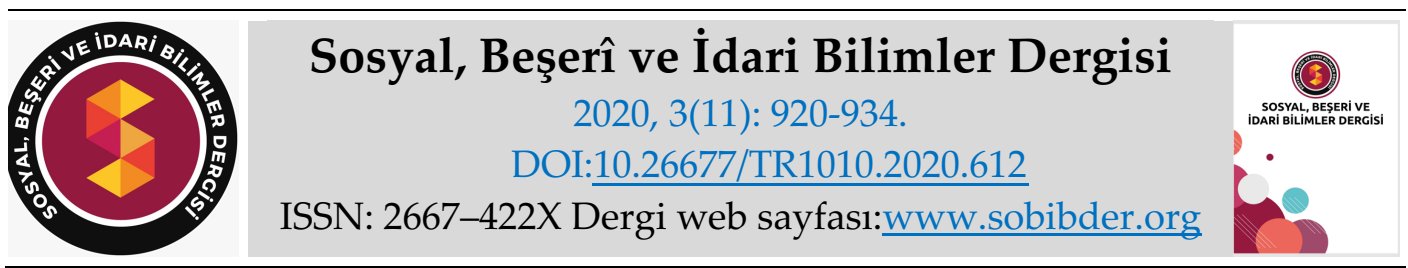

KAVRAMSAL MAKALE

\title{
Mevcut Anayasa ve Yasalar Çerçevesinde Yerel Yönetimler ile Sivil Toplum Kuruluşları İlişkisinin İncelenmesi: Silivri Örneği
}

Şefika ERDOĞAN ÇAĞLAR, Bilim Uzmanı, Silivri Belediyesi, İstanbul, e-posta: sefikacaglar@silivri.bel.tr

ORCID: https://orcid.org/0000-0002-2942-0012

Öz

Bu çalışmada Mevcut Anayasa ve Yasalar Çerçevesinde Yerel Yönetimler ve Sivil Toplum Kuruluşları (STK) İlişkisi incelenmiştir. Türkiye'de toplumsal yönlendirmede etkin olan STK ve yerel toplumun ihtiyaçlarını karşılamak maksadıyla kurulan Yerel yönetimler birbirleri ile çalışma uyumu sağlayamadığından ortak çalışma yerine birbirlerine muhalefet eder duruma düşmüşlerdir. Bu aykırılığın ortadan kaldırılmasında STK'lar önemli yer tutmaktadır. Birinci bölümde, Yerel yönetimler ve STK'ların Mevcut Anayasa ve Yasalar kapsamında tanımı yapılmıştır. İkinci bölümde, 2004 ve sonrası Yerel yönetimlerin yapısı incelenerek günümüze kadar Yerel yönetimlerde yaşanan gelişmeler ele alınmıştır. Üçüncü bölümde STK'lar mevcut yasalarla açıklanarak Sivil toplum tanımı ve özelikleri, Türkiye' de STK'nın gelişimi, Sivil Toplum Kuruluşları ve Yerel Yönetimler, STK'ların Siyasete ve Yerel Siyasete etkisi ve Baskı Grupları ile olan ilişkisi ortaya konulmuştur. Son bölümde bu amaca yönelik İstanbul İli Silivri İlçesinde Sivil Toplum Kuruluşları arasından seçilen STK'lar ile mülakat yapılarak Yerel yönetimlerden beklentileri somut olarak tespit edilmeye çalışılmıştır. Çağdaş belediyecilikte belediyelerin bir diğer önemli görevi de ekonomik kalkınmaya odaklanmaları ve bu amaçlarla da iş birliğine gitmeleri gerekliliğidir. Ancak Belediye Kanunu'nda STK'lar ile belediyelerin bu görevi nasıl yapacakları ve neler yapmaları gerektiği net olarak belirtilmemiştir. "Mahallin müşterek ihtiyaçlarını" karşılamak maksadıyla kurulan belediyelerin, STK'ların en önemli paydaşı olup, onlarla neredeyse hiç ilişkiye girmemesi ya da onlara kolaylık sağlayacak hizmetleri, beklentileri bilmediği için sunamaması birçok olumsuzluğa neden olmaktadır. Belediyeler "Hemşerilik hukukunu" pekiştirmede zayıf kalmakta ve amaca ulaşamamaktadırlar. Bu amaca ulaşmanın öncelikli yolu STK'larla, onların kuruluş amaçlarına yönelik faaliyetlerinde iş birliğinde bulunmaktır. Çalışmada yapılan STK mülakatlarının belediyelerin bu görevlerini yerine getirmelerine yardımcı olacağı değerlendirilmektedir.

Anahtar Kelimeler: Yerel Yönetimler, Sivil Toplum Kuruluşları, Baskı Grupları.

Makale Gönderme Tarihi: 09.06.2020

Makale Kabul Tarihi: 01.11.2020

\section{Önerilen Atıf:}

Çağlar Erdoğan, Ş. (2020). Mevcut Anayasa ve Yasalar Çerçevesinde Yerel Yönetimler ile Sivil Toplum Kuruluşları İlişkisinin İncelenmesi: Silivri Örneği, Sosyal, Beşeri ve İdari Bilimler Dergisi, 3(11): 920-934.

(C) 2020 Sosyal, Beşerî ve İdari Bilimler Dergisi. 


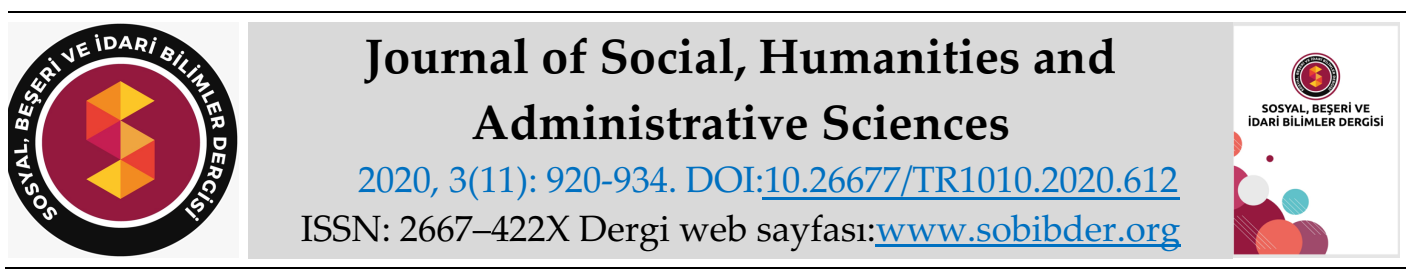

CONCEPTUAL PAPER

\title{
Investigation of the Relationship Between Local Governments and Civil Society Organizations the Framework of the Existing Constitution and Laws: Case of Silivri
}

\author{
Şefika ERDOĞAN ÇAĞLAR, MSc., Silivri Municipality, İstanbul, e-mail: \\ sefikacaglar@silivri.bel.tr \\ ORCID: https://orcid.org/0000-0002-2942-0012
}

\begin{abstract}
This study is on the investigation of the relationship between the Local Governments and NonGovernmental Organisations (NGO) within the Constitution and Official Laws framework. Because of disalignation between the NGOs, that are very effective on the guidance of Turkish society and the Local Governments that are formed to meet the need the society, instead of coordination, they oppose each other. Non-Governmental Organisations have an important role to resolve this contradiction. In the first chapter of this study, the definitions of Local Governments and NGO's were made, under the Current Constitution and Law. In the second chapter, the structure of Local Governments after 2004 and the developments on this area were investigated. In the third chapter, NGO's were explained according to the current law and the definition and characteristics of Non-Government, the development of NGO's in Turkey, NonGovernmental Organisations and Local Governments, the impact of NG's on the Territorial and Local Policies and the relationship with the Pressure Groups were brought up. In the last chapter, the expectations of the local administrations were determined by interviewing the NGO's selected from non-governmental organizations in Silivri district of Istanbul. Another important task of the Municipalities in Contemporary Administration of Municipalities is to focus on economic development and the necessity of cooperating for these purposes. However, the Municipal Law does not clearly state how NGO's and Municipalities would perform this task and what they should do. The municipalities that are established "to meet the common needs of locality" are the most important shareholder of NGO's and not having any kind of relationships or provide any services or facilities due to lack of knowledge of them, cause many problems. The municipalities are weak in reinforcing "Citizenship Law" and fail to achieve their purposes. The primary and only way to achieve this objective is to cooperate with NGO's in their activities aimed at establishment. NGO interviews conducted in the study would be very helpful for municipalities in fulfilling these duties.
\end{abstract}

Keywords: Local Governments, Non - Governmental Organizations, Pressure Groups.

Received: 09.06.2020

Accepted: 01.11.2020

\section{Suggested Citation:}

Çağlar Erdoğan, Ş. (2020). Investigation of the Relationship Between Local Governments and Civil Society Organizations the Framework of the Existing Constitution and Laws: Case of Silivri, Journal of Social, Humanities and Administrative Sciences, 3(11): 920-934.

(C) 2020 Sosyal, Beşerî ve İdari Bilimler Dergisi. 


\section{Gíriş}

Türk demokrasisinde iki temel yerel unsurdan biri Yerel yönetim bir diğeri de Sivil Toplum Kuruluşlarıdır. Ülkemizde toplumsal yönlendirmede etkin olan STK ve yerel toplumun ihtiyaçlarını karşılamak maksadıyla kurulan Yerel yönetimler birbirleri ile çalışma uyumu sağlayamadığından ortak çalışma yerine birbirlerine muhalefet eder duruma düşmüşlerdir. Bu aykırılığın ortadan kaldırılması amacıyla STK'lar önemli yer tutmaktadır. Her ikisinin mevzuatında da birbirlerine karşı görev ve sorumlulukları tanımlanmamıştır. Bu nedenle karşılıklı beklentiler yerine getirilmeme ve kaos ortamı oluşturulmaktadır. Bunun önüne geçilmesi için bu çalışmanın bu boşluğu dolduracağı düşünülmektedir. Bu amaçla bu çalışma tamamlanmıştır. Mülakat sonuçları STK'ların Yerel yönetimlere önerileri olarak teze yansitılmıştır. Bundan sonraki aşama kanun yapıcının bu önerilere kulak vermesi ve STK ve Yerel yönetim uyumunun sağlanmasına yönelik hukuki alt yapının sağlanmasıdır.

Bu çalışmada Mevcut Anayasa ve Yasalar Çerçevesinde Yerel Yönetimler ve Sivil Toplum Kuruluşları İlişkisi incelenmiştir. Birinci bölümde, Yerel yönetimler ve STK'ların mevcut Anayasa ve Yasalar kapsamında tanımı yapılmıştır. İkinci bölümde, 2004 ve sonrası Yerel yönetimlerin yapısı incelenerek günümüze kadar Yerel yönetimlerde yaşanan gelişmeler ele alınmıştır. Üçüncü bölümde STK'lar mevcut yasalarla açılanarak Sivil toplum tanımı ve özellikleri, Türkiye' de STK'nın gelişimi, Sivil Toplum Kuruluşları ve Yerel yönetimler, STK'ların Siyasete ve Yerel Siyasete etkisi ve Baskı Grupları ile olan ilişkisi ortaya konulmuştur. Son bölümde bu amaca yönelik İstanbul İli Silivri İlçesinde Sivil Toplum Kuruluşları arasından seçilen STK'lar ile mülakat yapılarak yerel yönetimlerden beklentileri somut olarak tespit edilmeye çalışılmıştır.

İdare kuruluş ve vazifeleriyle bir bütündür ve yasayla düzenlenir (T.C. 1982 Anayasası). Mahalli İdareler; vilayet, belediye veya köy halkının yerel ortak gereksinimlerini karşılamak üzere kuruluş temelleri yasayla belirtilen ve karar mekanizmaları yine yasada gösterilen seçmenler tarafından seçilerek oluşturulan kamu tüzel kişileridir. Mahalli İdareler olarak da adlandırılan yerinden yönetim 5393 sayılı Belediye Kanunu'nun 3. maddesine göre (5393 sayılı Belediye Kanunu); "Belediye, belde sakinlerinin mahalli müşterek nitelikteki ihtiyaçlarını karşılamak üzere kurulan ve karar organı seçmenler tarafından seçilerek oluşturulan, idari ve mali özerkliğe sahip kamu tüzel kişisidir".

Ayrıca 5393 sayılı Belediye Kanunu'nun 13. maddesine göre "Herkes ikamet ettiği beldenin hemşerisidir. Hemşerilerin, belediye karar ve hizmetlerine katılma, belediye faaliyetleri hakkında bilgilenme ve belediye idaresinin yardımlarından yararlanma hakları vardır. Yardımların insan onurunu zedelemeyecek koşullarda sunulması zorunludur. Belediye, hemşeriler arasında sosyal ve kültürel ilişkilerin geliştirilmesi ve kültürel değerlerin korunması konusunda gerekli çalışmaları yapar. Bu çalışmalarda üniversitelerin, kamu kurumu niteliğindeki meslek kuruluşlarının, sendikaların, sivil toplum kuruluşları ve uzman kişilerin katılımını sağlayacak önlemler alınır." denilmektedir.

Türkiye'de hukuki mevzuata bağlı kalınarak beş tür sivil toplum kuruluşundan bahsedilebilir. Bunlar; dernekler, vakıflar, sendikalar, meslek odaları ile kooperatifler ve birliklerdir (Türkiye Üçüncü Sektör Vakf1, 2011:61).

Dernekler Kanunu'na göre “Herkes, önceden izin almaksızın dernek kurma ve bunlara üye olma ya da üyelikten çıkma hürriyetine sahiptir. Hiç kimse bir derneğe üye olmaya ve dernekte üye kalmaya zorlanamaz (Dernekler Kanunu)." Sivil toplum kuruluşları genel olarak kamu 
kurumları dışındaki yasal örgütlenmeler olarak ifade edilmektedir. STK'lar, sivil toplum kavramından doğmuştur. Sivil toplum, devlet erki dışındaki toplumsal yapıların, bireylerin denetim ve baskı görmeden çeşitli konularda etkin oldukları bir modeli ifade etmektedir (Öner, 2001:59). Sivil toplum kuruluşları gönüllü insanların bir araya gelerek belli bir amaç etrafında toplanması sonucu oluşur. Devlet ile yurttaş arasında bir köprü görevi görmektedirler. Bu nedenle demokrasinin gelişmesine önemli katkıları bulunmaktadır.

Başka kültürlerde başka şekillerde ifade ediliyor olsa da Sivil Toplum Kuruluşları; toplumsal fayda için çalışan, demokrasinin gelişmesine katkı sağlayan, kâr amacı olmayan, iktidardan ayrı çalışmalar gösteren, bireylerin ortak hedef ve amaçlarına bakıldığında ise, politik iradeyi ve idareyi kamuoyu oluşturmak suretiyle etkileyebilen bir teşkilatlandırma türüdür (Tosun, 2004:116). Yerel yönetimlerin halka daha yakın kurumlar olduğu, sivil önceliklerin katılımının çok daha kolay olduğu ve hatta birer sivil toplum kuruluşu olarak kabul edilebilecekleri söylenmektedir (Yüksel, 2003:177). Benzer özellikleri olsa da Yerel yönetimler bir sivil toplum kuruluşu değildir. Yerel yönetimler, merkezi yönetimin dişında olmak üzere, yerel bir topluluğun ortak gereksinmelerini karşılamak amacıyla oluşturulan, karar organlarını doğrudan halkın seçtiği, demokratik ve özerk yönetim basamaklarıdır (Kamu Yönetimi Sözlüğü, 1998:258).

Mahalli İdareler, kamunun kendi hür iradesi ile seçmiş olduğu mekanizmalar vasıtasıyla kendini idare eden kuruluşlardır. Bu hususiyetleriyle bir sivil cemiyet idaresi olarak, tabana dayalı şekilde ortaya çımış olmalarından ötürü, hemşerilik bilincinin gelişmesine fayda sağlayarak, demokratik katılımın gerçekleşmesini sağlarlar (Öner, 2000:133). Demokrasinin vazgeçilmez öğelerinden olan Yerel yönetimler aynı zamanda yurttaşların birbirleri ile olan ilişkilerinin güçlenmesi için sosyal ve kültürel etkinlikler yaparak, daha katılımcı ve etkin bir rol oynarlar. Mahalli İdareler, sivil toplum kuruluşları gibi merkezi hükümetin kuvvetini sinırlarlar ve kamudaki güçleri dengeleyerek, demokratik toplum oluşumuna katkı sağlarlar (Görmez, 1997:10).

Siyasetin yerel unsurlar sonucu oluştuğunu düşünecek olursak Yerel yönetimlerin önemini daha iyi anlamış oluruz. Yerel yönetimler ile birlikte yerel siyasetin bir parçasını oluşturan sivil toplum kuruluşları siyasal yapının dışında olan ancak siyasal yapıya etki eden ve siyasal yapıdan da etkilenen oluşumlardır. Sivil toplum kuruluşları yerel siyaset içerisinde önemli bir aktördür. Bu kuruluşlar, yurttaşların beklentilerini yerel kamu otoritesine ileten ve yerel karar alma sürecini etkilemeye çalışan önemli siyasal araçlar olarak öne çıkmaktadır. STK'lar kuruluş amaçları doğrultusunda çalışmalar yaparak yerel halkın desteğiyle önemli bir rol üstlenmektedir.

\section{ANAYASADA YEREL YÖNETIMLER}

Türkiye Cumhuriyeti 1982 Anayasasının 123- 126 ve 127. maddelerinde idarenin kuruluşu düzenlenmiştir. 123. Maddeye göre; "İdare kuruluş ve görevleriyle bir bütündür ve kanunla düzenlenir. İdarenin kuruluş ve görevleri merkezden yönetim ve yerinden yönetim esaslarına dayanır. İllerin idaresi ise yetki genişliği esasına dayanır. 126. Maddeye göre; “Türkiye, merkezi idare kuruluşu bakımından, coğrafya durumuna, ekonomik şartlara ve kamu hizmetlerinin gereklerine göre, illere; iller de diğer kademeli bölümlere ayırılır. İllerin idaresi yetki geniş̧liği esasına dayanır. Kamu hizmetlerinin görülmesinde verim ve uyum sağlamak amacıyla, birden çok ili içine alan merkezi idare teşkilatı kurulabilir. Bu teşkilatın görev ve yetkileri ise kanunla düzenlenir. 127. Maddeye göre; "Mahalli idarelerin belirli kamu hizmetlerinin görülmesi amacı ile kendi aralarında Cumhurbaşkanının izni ile birlik kurmaları, görevleri, yetkileri, maliye ve kolluk işleri ve merkezi idare ile karşllıklı bağ ve ilgileri kanunla düzenlenir. Bu idarelere, görevleri ile orantılı gelir kaynakları sağlanır (T.C. 1982 Anayasası)." 


\section{Yerel Yönetimler}

Türkiye'de Yerel Yönetimler kapsamında bulunan kuruluşlar yaygın anlamda (Ökmen ve Parlak, 2010:140);

- Belediyeler

- İl özel idareleri

- Belediyelere bağlı idareler

- Mahalli idare birlikleri

- Kalkınma ajansları ve gençlik spor il müdürlükleri olarak tanımlanabilir.

\section{Yasal Çerçeveye Göre Yerel Yönetimler}

Belediye sistemine göre 5216 sayılı kanuna tabi Belediyeler Büyükşehir Belediyeleridir. 5393 sayılı kanuna tabi Belediyeler; İl ve İlçe Belediyeleri, Büyükşehir sınırları içinde yer alan ilçe Belediyeleri ve Belde Belediyeleridir (https://www.mevzuat.gov.tr/MevzuatMetin/1.5.5393.pdf).

5393 sayılı Belediye Kanunu 2005 yılında yürürlüğe girmiştir. Böylece 1930 yılından bu yana yürürlükte olan 1580 sayılı Belediye Kanunu yürürlükten kaldırılmıştır (Özden ve Zorlu, 2010:39). 5393 Sayılı Belediye kanununun 3. maddesine göre; “Belediye, belde sakinlerinin yerel ortak nitelikteki gereksinimlerini karşılamak üzere kurulan ve karar organı seçmenler tarafından seçilerek oluşturulan, idari ve mali özerkliğe sahip kamu tüzel kişisidir (5393 sayılı Belediye Kanunu)."

\section{Belediyelerin STK'lara Yönelik Görevleri}

5393 sayılı Belediye Kanunu'na göre Belediyelerin STK'lara yönelik görevi bulunmamaktadır. Ancak Belediye yöneticisi ile yapılan görüşmede; STK'lar ile iş birliği yapılarak destek olunduğu, birlikte ortak projeler yürütüldüğü ifade edilmiştir. Ayrıca imkânlar dâhilinde teknik ve lojistik destek verildiği söylenmektedir. İlçeyi temsilen yapılan iş birliği protokolleri ile uluslararası yarışmalar ve festivallerde bölgeyi tanıtmak ve turizmi geliştirmek için yer ayarlama, otobüs, araç ve ses sistemi desteği verilerek gidiş-geliş masrafı, ulaşım, konaklama ve kıyafet yardımı yapıldığı ifade edilmektedir. Ayrıca kanun kapsamında Spor kulüplerine ayni ve nakdi yardım yapıldığı da ifade edilmektedir (Terlikçi, 2020).

TERLIKCÇİ Meral, Silivri Belediyesi Kültür ve Sosyal İşler Müdürlüğü, 2020.

5393 sayılı Belediye Kanunu'nun 14. maddesine göre (5393 sayılı Belediye Kanunu); “Belediye gerektiğinde, sporu teşvik etmek amacıyla gençlere spor malzemesi verir, amatör spor kulüplerine ayni ve nakdî yardım yapar ve gerekli desteği sağlar, her türlü amatör spor karşılaşmaları düzenler, yurt içi ve yurt dışı müsabakalarda üstün başarı gösteren veya derece alan öğrencilere, sporculara, teknik yöneticilere ve antrenörlere belediye meclisi kararıyla ödül verebilir. Gıda bankacılığı yapabilir. Belediyelerin birinci fıkranın (b) bendi uyarınca, sporu teşvik etmek amacıyla yapacakları nakdi yardım, bir önceki yıl genel bütçe vergi gelirlerinden belediyeler için tahakkuk eden miktarın; büyükşehir belediyeleri için binde yedisini, diğer belediyeler için binde on ikisini geçemez."

Aynı kanunun 75. maddesine göre (5393 sayılı Belediye Kanunu); “Belediye, belediye meclisinin kararı üzerine yapacağı anlaşmaya uygun olarak görev ve sorumluluk alanlarına giren konularda; Yurt içindeki ve Çevre ve Şehircilik Bakanlığının izniyle yurt dışındaki belediyeler ve mahallî idare birlikleriyle karşılıklı iş birliği yapılmasına; kardeş kent ilişkileri kurulmasına, ekonomik ve sosyal ilişkileri geliştirmek amacıyla kültür, sanat ve spor gibi alanlarda faaliyet ve projeler gerçekleştirilmesine; bu çerçevede arsa, bina ve benzeri tesisleri yapma, yaptırma, kiralama veya tahsis etmeye karar vermektedir." 


\section{Kent Konseyleri}

5393 sayılı Belediye Kanunu'nun 76. maddesince (Kent Konseyi Yönetmeliği): “Kent Konseyi kent yaşamında; kent vizyonunun ve hemşerilik bilincinin geliştirilmesi, kentin hak ve hukukunun korunması, sürdürülebilir kalkınma, çevreye duyarlılık, sosyal yardımlaşma ve dayanışma, saydamlık, hesap sorma ve hesap verme, katılım ve yerinden yönetim ilkelerini hayata geçirmeye çalışır. Belediyeler kamu kurumu niteliğindeki meslek kuruluşlarının, sendikaların, noterlerin, varsa üniversitelerin, ilgili sivil toplum örgütlerinin, siyasi partilerin, kamu kurum ve kuruluşlarının ve mahalle muhtarlarının temsilcileri ile diğer ilgililerin katılımıyla oluşan kent konseyinin faaliyetlerinin etkili ve verimli yürütülmesi konusunda yardım ve destek sağlar. Kent konseyinde oluşturulan görüşler belediye meclisinin ilk toplantısında gündeme alınarak değerlendirilir. Kent konseyinin çalışma usul ve esasları İçişleri Bakanlığınca hazırlanacak yönetmelikle belirlenir" şeklinde ifade edilmiştir.

\section{ANAYASADA SİVIL TOPLUM KURULUŞLARI}

Türkiye Cumhuriyeti 1982 Anayasasına göre Sivil Toplum Kuruluşları;

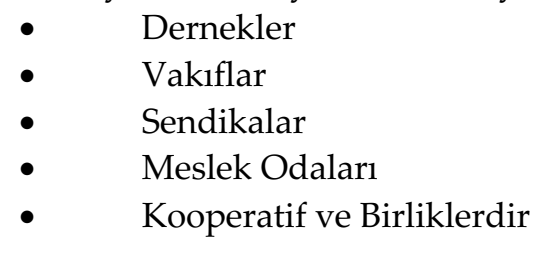

\section{Sivil Toplum Kuruluşları}

Türkçe 'de "sivil toplum kuruluşları" olarak ifade edilen kavram, Avrupa ülkelerinde "non govermental organizations" biçiminde kullanılmaktadır ve hükümet dışı kuruluşlar veya devlet dışı örgütler anlamına gelmektedir.

$\mathrm{ABD}$ 'de ise sivil toplum kuruluşları "public voluntary organizations", "gönüllü kamu kuruluşları" olarak adlandırılmaktadır. Değişik kültürlerde farklı biçimlerde tanımlanıyor olsa da sivil toplum kuruluşları; kamu yararına çalışan, demokrasinin gelişmesine katkı sağlayan, kâr amacı olmayan, devletten ayrı çalışma alanı olan, fertlerin ortak gaye ve hedeflerine bakıldığında ise, politik iradeyi ve yönetimi kamuoyu oluşturmak suretiyle etkileyebilen bir teşkilatlanma çeşididir (Tosun, 2004:1-16).

Sivil toplumla ilgili olarak Amerikan kaynaklarında en yeni kavram CBO 'lardır. (CBO: Community Based Organizations) Bu terimle, mahalle düzeyinde, yerel halka dayalı örgütlenmeler kastedilmektedir. Yerel halkın bir araya gelerek oluşturdukları örgütler olarak da tanımlanabilir. Özellikle Amerika'da yaygınlaşan ve gittikçe etkisini her alanda arttırdığ gözlenen sivil toplum kuruluşları, önde gelen yönetim gurusu Peter Drucker tarafından ABD'nin en büyük yenilik ve itici gücü olarak gösterilmektedir (Mete, 1998: XI).

"Yurttaşların ortak bakış, ortak çıkar, ortak duyarlılık, ortak talep ve benzeri temelinde gönüllü olarak bir araya gelerek; devletin hukuki, idari, üretici ve kültürel organlarının dışındaki alanda meydana getirdikleri; dernek, vakıf, sivil girişim, platform, ilişki ağı ve benzerlerinden oluşan yapılara ve etkinliklere sivil toplum kuruluşları denir (Akbal, 2017:105)."

Kavramsal olarak tanımlanmasından sonra STK'ların şekil ve işlevlerini incelemek gerekmektedir. Sivil toplum kuruluşlarının belirlenmiş görevleri şu şekilde sıralanabilir (Güneş, 2004:5):

1. Kamuoyu oluşturmak yolu ile bireylerin taleplerinin dile getirilmesine yardımcı olmak, 
2. Çoğulcu toplum yapısının oluşumunu sağlamak amacıyla piyasadaki sermayeleşme ve egemen piyasa değerlerine karşı dengeleyici bir unsur olmak,

3. Kendi içlerinde oluşturdukları katılımcı ve çoğulcu bir kültürle beslenmiş ve aynı zamanda yönetim deneyimi de edinmiş bireylerin yetişmesini sağlamak,

4. Pilot projeler üretmek, bu projelere kaynak bulmak ya da bu projeleri uygulamaya geçirmek yoluyla eğitim, sosyal refah ve istihdam konularında hükümet politikalarına paralel ya da alternatif sorumluluklar alabilmek.

\section{Dernekler}

Yürürlükte olan yasal mevzuata göre derneklerin tanımı Türk Medeni Kanunu'nda yapılmışır. Türk Medeni Kanunu'nun 56. maddesine göre (Türk Medeni Kanunu); “Dernekler, gerçek veya tüzel en az yedi kişinin kazanç paylaşma dışında belirli ve ortak bir amacı gerçekleştirmek üzere, bilgi ve çalışmalarını sürekli olarak birleştirmek suretiyle oluşturdukları, tüzel kişiliğe sahip kişi topluluklarıdır" şeklinde ifade edilmiştir.

Kanunda belirtildiği üzere "Dernekler belli bir amaç etrafında toplanan yasal bir yapıyı ifade eder. Bu kuruluşlar bilgi ve becerilerini paylaşarak topluma hizmet etmeye çalışırlar. Maddi beklenti gütmeden toplumsal hizmete fayda sağlamak amacıyla yeni fikirler üreterek halka hizmet etmiş olurlar".

Aynı maddenin ikinci fıkrasında hukuka veya ahlâka aykırı amaçlarla dernek kurulamayacağı belirtilmiştir. Kanun'un 57. maddesinde ise "Herkes, önceden izin almaksızın dernek kurma hakkına sahiptir" denilerek dernek kurmanın izne bağlı olmadığı belirtilmiştir. Dernek kurma konusunda hiçbir izin alınmaması bu yapıların demokratik bir oluşum olduğunun göstergesidir.

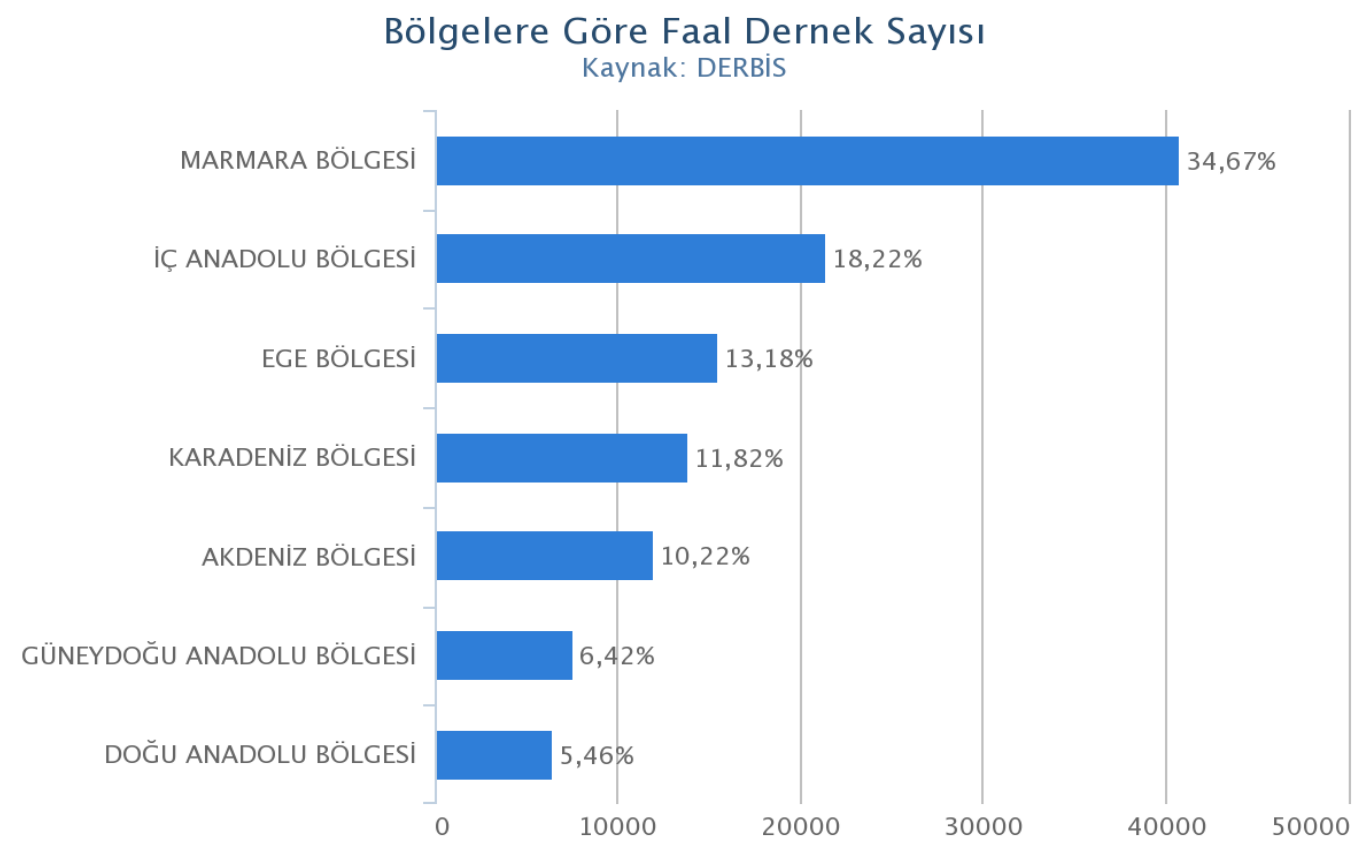

Grafik 1. Bölgelere Göre Faal Dernek Sayısı

(https://www.siviltoplum.gov.tr/dernek-sayilari) 
Yasanın desteğiyle gelişen dernekler, demokrasinin gelişmesine de önemli katkılar sağlamaktadırlar. Derneklerin gelişmesi ile birlikte siyasal katılımda artmış olacaktır. Halkın siyasete katılımının artması demokrasiyi etkin hale getirerek bölgenin gelişmesine katkı sağlayacaktır (Çağlar, 2020:19).

\section{Vakıflar}

5737 sayılı Vakıflar Kanunu vakıfların kuruluşunun Türk Medeni Kanunu hükümlerine göre kurulacağını ifade etmiştir. Vakıflar kanununda vakıfların çeşitleri, kuruluş şekilleri, yönetici seçme kuralları, mal edinme yolları ve kamu kurumu olan vakıflar genel müdürlüğü ile olan ilişkilerini belirten düzenlemeler yer almaktadır. "Vakıflar, gerçek veya tüzel kişilerin yeterli mal ve hakları belirli ve sürekli bir amaca özgülemeleriyle oluşan tüzel kişiliğe sahip mal topluluklarıdır (Vakıflar Kanunu)." Vakıflar kuvvetli bir STK oluşumudur.

\section{Sendikalar}

Sendikalar kamu görevlilerinin ortak, ekonomik, sosyal ve meslekî hak ve menfaatlerini korumak ve geliştirmek için bir araya gelen tüzel kişiliğe sahip kuruluşlardır. İşçilerin veya işverenlerin çalışma ilişkilerinde, ortak ekonomik ve sosyal hak ve menfaatlerini korumak ve geliştirmek için en az yedi iş̧̧i veya işverenin bir araya gelerek bir işkolunda faaliyette bulunmak üzere oluşturdukları tüzel kişiliğe sahip kuruluşlardır. Sendikalar kişinin çalışma yaşamındaki sosyal ve ekonomik haklarını sağlamak amacıyla önemli çalışmalar yapmaktadırlar (Sendikalar ve Toplu İşs Sözleşmesi Kanunu).

Sendikaların temel amacı; "üyelerinin hak ve menfaatleri için çalışmak, bunları korumak ve geliştirmektir. Sendikalar, genellikle çalışma koşulları ve işyeri düzeyinde ortaya çıkan sorunları çözme amacı taşırken, ulusal ve uluslararası düzeyde ortaya çıkan sosyal ve politik alanlarda da faaliyet göstermektedirler."

\section{Meslek Kuruluşları}

Kamu kurumu niteliğindeki meslek kuruluşlarının anayasal statüsü sivil toplum, demokrasi ve devletle olan ilişkisi Osmanlı İmparatorluğu'nun son dönemlerine kadar uzanmaktadır. Osmanlı'dan alınan yapı Türkiye Cumhuriyeti'nin kuruluşu sonrasında da temel olarak korunmuş ve zaman içerisinde yeni bir hüviyet kazanmıştır. Özellikle 1950 sonrası dönemde bu kapsama alınan meslekler ve meslek kuruluşlarında görülen artış ve 1960 askeri darbesi sonrasında yürürlüğe konulan 1961 Anayasası'yla kazanılan anayasal statü ve ayrıcalıklar mevcut yapıyı güçlendirmiştir. Dolayısıyla, bu kuruluşları yalnızca hukuki nitelikleri, idari statüleri ve örgütlenme biçimleri bakımından değil; siyasi işlevleri, faaliyetleri ve nitelikleri bakımından da değerlendirmek gerekmektedir (Ekrem, 2012:7).

\section{Kooperatif ve Birlikler}

1982 Anayasasının 171. maddesi “Devlet, milli ekonominin yararlarını dikkate alarak, öncelikle üretimin arttırılmasını ve tüketicinin korunmasını amaçlayan kooperatifçiliğin gelişmesini sağlayacak tedbirleri alır. Kooperatifler, devletin her tülü kontrol ve denetimine tabi olup, siyasetle uğraşamaz ve siyasi partilerle iş birliği yapamazlar" şeklindedir. 1982 anayasası kooperatiflere politika yasağ 15). Daha sonra kooperatiflerin politika yasağı, siyasi partilerle iş birliği yapamayacağını ve hükümetin denetimine tabi olduğu doğrultusundaki hükümler 1996 yılında anayasadan çıkarılmıştır (Hazar vd., 1997:16). 


\section{Sivil Toplum Kavramı}

Sivil toplum kavramını tanımlamak biraz zordur. Sivil toplum denilince birçok iktidarın aklına dernekler, vakıflar, meslek odaları, kitle iletişim araçları, sendikalar ve bunlara benzer kurumlardaki katılım alanları gelmektedir. Sivil toplum kavramı şimdiki anlamıla ilk kez Ferguson' un "Sivil Toplumun Tarihi Üzerine Bir Deneme" adlı çalışmasında 1767 yılında kullanılmıştır (Miller vd., 1995:25).

\section{Türkiye'de STK'nın Gelişimi}

Bilhassa, 12 Eylül 1980 askeri darbe sonrası sağda ve solda var olan temel siyasal akımlar etkili iktidar geleneğinin dönüştürülmesi ve demokratik olarak denetlenmesi gerektiği yönünde müşterek bir davranış sergilenmiş ve bu dönüşüm ve denetimin motor gücü olarak da sivil toplum kavramı ön plana çıkmıştır (Yıldız, 2007:53).

Avrupa Birliğine üye olmak isteyen Türkiye, STK alanında hukuki mevzuatı, dünyanın günümüzde ulaştığı anlayışa göre yeniden düzenlemeyi kabul etmiştir. 1996 yılında İstanbul'da yapılan Habitat II konferansında yayınlanan "İstanbul Deklarasyonu'nda, "Habitat Gündem'inde ve 'Ulusal Eylem Planı'nda, Türkiye'de de hükümet, diğer ülke hükümetleri gibi, sivil toplum kuruluşlarının meşruiyet alanını genişleteceğine ve kamu hizmetlerinin görülmesinde sivil toplum kuruluşlarıyla ortaklıklar yapacağına ilişkin sözler vermiştir (Çağlar, 2020: 39.)

Günümüzde Türkiye'deki yasal yönetmeliklerin STK'lar alanındaki gelişmeleri kolaylaştırmadığı, aşırı denetim kaygısı altında birçok girişimi daha doğmadan ortadan kaldırdığı söylenebilir. Böyle bir düşünceden dolayı yeni yasal yönetmeliklerin gerçekleştirmesi gerekenleri dört başlık altında toplayabiliriz. Bunlar (Tekeli, 2002:25);

1. STK'ların doğuşunun kolaylaştırılması yoluyla yurttaşların bu konudaki girişimlerinin özendirilmesi,

2. STK'ların içte ve dışta ilişki kurmalarının, network oluşturmalarının kolaylaştırılması yoluyla kapasitelerinin geliştirilmesi,

3. Şeffaflı̆̆ın artırılması,

4. STK'ların faaliyetlerinin sonradan yargı yolu ile denetlenmesi.

\section{Sivil Toplum Kuruluşlarının Özellikleri}

STK'ların özelliklerinden biri özerkliktir. Gönüllü olarak bir araya gelmeleri ve devletten bağımsız olmaları STK'lara özerk bir özellik kazandırır. Aynı zamanda kuruluş amaçlarını kendilerinin belirlemesi ve faaliyetleri için onay almak zorunda olmaması STK'ların demokratik bir hakka sahip olduklarını gösterir. Genel olarak STK'ların özellikleri: Özerklik, siyasi otoriteyi eleştirebilmek, baskı mekanizması olmak, katılıma imkân vermek, serbestçe kurulabilmek, bireysel istekle üye olmak, kamu yönetimi teşkilatı dışında olmaktır.

Ayrıca sivil toplumun özellikleri şöyle gruplandırılabilir. Bunlar (Acı, 2005: 25-26):

- Genel olarak kamusal alandaki tüm bireylerin katılımına açık kuruluşlar, dernekler, sivil oluşumlar gibi yurttaşların gönüllü katılımı ile oluşan birlikteliklerdir.

- $\quad$ STK'ların siyasal iktidar karşısında özerk ya da bağımsız olmaları esastır.

- $\quad$ Tek renkli değildirler, heterojen yapıdadırlar.

- $\quad$ STK'lar yasal kurumlardır. Bu nedenle bu kuruluşların kendi içişlerinde insan haklarına saygı kurumsal düzeyde garanti altındadır.

- $\quad$ STK'larda üyeler arasında sivil davranış ruhu egemendir. Bu nedenle aralarında karşılıklı saygı ve dayanışma ruhu ile hareket ederler. 
- $\quad$ STK'lar aynı zamanda soyut bir potansiyeli bünyesinde barındırırlar. Bu kuruluşlar kendiliğinden oluşmuşlardır.

Sivil toplum kuruluşlarını ayırt eden özelliklerden ilki, gönüllülük ve özel alandan fedakârlık yapılmasına dayandırılmalarıdır.

\section{Sivil Toplum Kuruluşları ve Yerel Yönetimler}

Şehirlerin ve şehir yönetimlerinin gün geçtikçe artan iş yükü, katılım süreçlerinin gelişmesi, sivil toplum kuruluşlarının yeni rolleri ve görevleri gibi gelişmeler karşısında, tüm dünyada "yerellik" kavramının tartışılmaya başlandığı görülmektedir. Üç ana bölümden oluşan Gündem 21 kapsamında yerel yönetimler ve sivil toplum kuruluşları, "Temel grupların rollerinin geliştirilmesi" başlıklı üçüncü bölümde ele alınmaktadır. Sivil toplum kuruluşlarının ilk kez ayrı bir başlık altında ele alındığı 27'inci Bölümde bu kuruluşların katılımcı demokrasinin biçimlendirilmesinde ve uygulanmasındaki "can alıcı rolü" ne dikkat çekilmekte ve bunların oynadığı "bağımsız rolün doğasının gerçek bir katılımı gerektirdiği" ve bu nedenle bağımsızlığın, "sivil toplum kuruluşlarının temel niteliği ve gerçek katılımın ön koşulu olduğu" vurgulanmaktadır (http://cevre.mf.duzce.edu.tr/).

Sivil toplum kuruluşları mahalli idarelerin kararları üzerinde etkili olmalıdır. Çünkü (Akbal, 2017:122);

1. Sivil toplum kuruluşları kararların oluşumuna katılır ise, öz potansiyellerini ortaya koyarlar ve uygulanan kararlara ve yürütülen etkinliklere katılmış olurlar.

2. Yerel ölçekte alınan kararlarda rasyonel karar verme sürecini tetiklerler.

3. Kendilerini kanıtlama amacı ile yerel yönetim kararlarına karşı çıarlar ya da desteklerler.

4. Kamu yararının bekçisi durumuna gelirler. Onların kamu yararına aykırı buldukları uygulamaların gerçekleşmesi oldukça zorlaşır.

5. Kendi yararlarını engelleyecek ya da geciktirecek uygulamalara da karşı çıkarlar ya da engellerler.

Yerel yönetim sürecine yerel halkı katmak, kuşkusuz seçimlerin biçimsel şartların dışında, gerçek katılım şartlarını sağlayarak, toplumdaki tüm tabakaların katılımını sağlamakla olur. Bu bağlamda, çeşitli meslek kuruluşları, sendikalar, kooperatif birlikleri, vakıflar, dernekler ve diğer gönüllü kuruluşlarla yerel yönetimler çeşitli alanlarda iş birliği ve ortak çalışmalar yapabilmektedirler. Burada iş birliği ile kastedilen (Güneş ve Tekgül, 2005:337);

1. STK'ların yerel yönetimlerin karar alma yani politika belirleme süreçlerine etkin olarak katılması

2. Yerel yönetimlerin STK'larla hizmet üretim ve sunumda iş birliği yapması

Ancak STK-Yerel yönetimler iş birliği konusunda en önemli sorunlardan bir tanesi her iki kurumunda nasıl temsil edileceği ve seçimi, hangi kriterlere göre karar verileceğinin belirlenmesidir. Bu sorunun çözümü için önerimiz yerel yönetimlerde "Sivil Toplum İlişkiler Biriminin" kurulması olmalıdır. Bu birim aynı zamanda STK -Yerel yönetimler kuruluşları için bir danışma mekanizması rolü oynayabilir (Çağlar, 2020:49).

Halka en yakın kurumlar olan yerel yönetimler halk ile sürekli iletişim içinde olarak yönetişim ilkesine göre hareket etmelidir. Kent konseyleri belediye ile üniversitelerin, sivil toplum örgütlerinin bir araya geldiği bir oluşum olması nedeniyle yönetişim felsefesine katkı 
sunmaktadır. Bölge halkının hizmet beklentilerini yerel yönetime ileten ve alınan kararları etkileyen sivil toplum kuruluşları yerel aktörler arasında önemli bir yer tutmaktadır.

Sivil toplum kuruluşlarının yerel düzeyde çok fazla etkin olduklarını ve çalışma yaptıklarını söyleyemeyiz. Bulunduğumuz zaman içinde birçok sivil toplum kuruluşu siyasi hayattan uzak durmayı tercih etmişledir. Sivil toplum kuruluşlarının mahalli kararların alınmasında daha etkin rol alabilmesi için kent konseyi çalışmaları başlatılmış, ancak mahalli idarecilerin bilinçsizliği, sivil toplum kuruluşlarının kendilerini bağımlı hissetmeleri, klasik idare anlayışı gibi birçok sebepten dolayı beklenen sonuçlar alınamamıştır.

Yerel siyasetin bir parçasını oluşturan sivil toplum kuruluşları siyasal yapının dışında olan ancak siyasal yapıya etki eden ve siyasal yapıdan da etkilenen oluşumlardır. Sivil toplum kuruluşları yerel siyaset içerisinde önemli bir aktördür. Bu kuruluşlar, yurttaşların beklentilerini yerel kamu otoritesine ileten ve yerel karar alma sürecini etkilemeye çalışan önemli siyasal araçlar olarak öne çıkmaktadır.

\section{Baskı Grupları ve STK'lar}

STK'lar nasıl baskı grubu olur; Siyasal amaç gütmeden bir araya gelen kişilerin oluşturdukları dernek, grup ve örgütler, belli koşulların gerçekleşmesiyle baskı grubu niteliğini kazanmaktadır. Baskı grubu olabilmek için asıl kıstas, grubun hükümetle arbedesi anında baskıcı özelliğe ehil olması gerekliliğidir. Baskı ekiplerinin ana öğelerini şu şekilde belirtmek uygundur (Akad, 1976:64-67):

A. Toplumdaki sosyal güçlerin bilinçli örgütlenmesi,

B. Kendi çıkarları doğrultusunda toplumsal çıkarlarını iktidara iletme,

C. Kitlenin gerçek iradesini belirleyen ve yönetime meşruluk kazandıran çoğulcu grupların varlığ gibi.

Sivil toplum kuruluşları ile yapılan görüşmeler sonucu elde edilen bulgular neticesine göre STK'ların yerel yönetimlerden öncelikli beklentisi birlikte ortak projeler yürüterek halka daha iyi hizmet sunmaktır. Yerel yönetimlerin yaptığı çalışmalara STK'ları da dâhil etmesi ve görüş alınması da istenmektedir. Ayrica genel olarak STK'lar belediyelerden yer talep etmekte ve kendilerine bütçe ayrılmasını da istemektedirler. Mevcut yasalar incelendiğinde bütün bu beklentilerin karşılanmasında yetersiz kaldığı tespit edilmiştir. Belediye Kanunu'nda bu anlamda yapılacak olan yeni yasal düzenlemelere ihtiyaç bulunmaktadır.

\section{SONUÇ}

5393 sayılı Belediye Kanunu'nun 13. maddesinde "Belediye, hemşeriler arasında sosyal ve kültürel ilişkilerin geliştirilmesi ve kültürel değerlerin korunması konusunda gerekli çalışmaları yapar. Bu çalışmalarda üniversitelerin, kamu kurumu niteliğindeki meslek kuruluşlarının, sendikaların, sivil toplum kuruluşları ve uzman kişilerin katılımını sağlayacak önlemler alınır." denilmektedir.

Ayrıca 75. maddede "Belediyeler kamu kurumu niteliğindeki meslek kuruluşlarının, sendikaların, noterlerin, varsa üniversitelerin, ilgili sivil toplum örgütlerinin, siyasi partilerin, kamu kurum ve kuruluşlarının ve mahalle muhtarlarının temsilcileri ile diğer ilgililerin katılımıyla oluşan kent konseyinin faaliyetlerinin etkili ve verimli yürütülmesi konusunda yardım ve destek sağlar" denilmektedir. 
Ancak Belediye Kanunu'nda STK'lar ile Belediyelerin bu görevi nasıl yapacakları ve neler yapması gerektiği net olarak belirtilmemiştir. Bu çalışma, STK'larla yapılan birebir mülakat yöntemiyle, STK'ların Belediyelerden beklentilerini net olarak ortaya koymaktadır. "Mahallin müşterek ihtiyaçlarını" karşılamak maksadıyla kurulan Belediyeler, STK'ların en önemli paydaşı olup, onlarla neredeyse hiç ilişkiye girmemesi ya da onlara kolaylık sağlayacak hizmetleri, beklentileri bilmediği için sunamaması birçok olumsuzluğa neden olmaktadır.

Öncelikle STK tanımı ve hukuki alt yapısının, Yerel yönetim tanımı ve hukuki alt yapısının incelenerek ortaya konulduğu bu çalışma, STK'ların ekonomik yaşamdaki önemini açıkça ortaya koymakta ancak belediyeden bu öneme mukabil destek ve anlayışın yeterince gösterilmediğini de ifade etmektedir. Çağdaş belediyecilikte belediyelerin bir diğer en önemli görevi de ekonomik kalkınmaya odaklanması ve bu amaçla STK'larla da iş birliğine gitmesidir.

Belediyeler "Hemşerilik hukukunu" pekiştirmede zayıf kalmakta ve amaca ulaşamamaktadırlar. $\mathrm{Bu}$ amaca ulaşmanın öncelikli ve tek yolu STK'larla, onların kuruluş amaçlarına yönelik faaliyetlerinde, iş birliklerinde bulunmaktır. Çalışmada yapılan STK mülakatları Belediyelerin bu görevlerini yerine getirmelerinde çok yardımcı olacaktır.

\section{ÖNERILLER}

1. Belediyeler, Belediye sınırları içerisinde yer alan sanayici ve iş adamları için daimî sergi ve fuar alanları oluşturmalıdır. Yılın 12 ayı açı tutulacak bu alanlara yurt içi ve yurt dışı ziyaretçiler için sürekli ulaşım imkânı sağlamalıdır.

2. Belediyeler sanayiler için kendi parseli içinde imar kolaylığı sağlamalıdır.

3. Belediye bütçesinden bölgedeki sanayi kuruluşlarına yönelik bütçeden bir destek payı ayırmalıdır. Bu pay yüzde 1 ile yüzde 10 arasında olmalıdır.

4. Belediyeler imar planlarında iş adamlarına ayrılacak alanların her türlü alt yapı ve üst yapısını hazır hale getirerek çok uygun fiyatlarla sunmalıdır.

5. Belediye Başkan yardımcılıklarından bir tanesini STK'lar için görevlendirmelidir. Atanan başkan yardımcısı ya da oluşturulacak birim STK'ların karşılaşacağı sıkıntı ve sorunların çözüm noktası olmalı, STK'ların yapacağı etkinliklere katılımcı, yol gösterici, kolaylaştıııcı olmalıdır.

6. Belediye bölgesinde bulunan bütün STK'lara eşit mesafede durmalıdır

7. Belediye toplum sağlığını her kesim için temel görev edinerek İzcilik ve Doğa Sporları adına parkurlar ve dinlenme alanları oluşturmalıdır.

8. Belediye ve STK ilişkileri sadece Kent Konseyleri vasıtasıyla olmamalıdır. STK'lar belediye meclisine önerge verebilmeli ve gözlemci sıfatılla meclise katılabilmelidir.

9. Belediyeler hemşerilik hukukunu geliştirecek etkinlikleri her bir yıllık çalışma dönemi içerisinde ay bazında yoğunlaştıracak şekilde düzenlemelidir.

10. Belediyeler STK'ları çözüm ortağı görerek onların gerek sosyal gerek eğitim projesinde yürütücü paydaş olmalarına sosyal fayda sağlamak adına yardımcı olmalıdır. Mali olmasa da maddi (mekân, ulaşım, araç, envanter) gibi destekler sunmalıdır.

11. Belediyeler beldelerinde kurulmasına izin verilmiş her STK'nın kuruluş amacının gerçekleşmesine yardımcı olmalıdır.

12. Belediyede alınan kararların STK temsilcilerinin de görüşüne sunulması ve daha sonra onaya sunulmasını sağlamalıdır.

13. Belediyeler yerel ekonominin geliştirilmesi için STK'ların "iktisadi işletmeleri" ile iş birliği yaparak yerel ekonomiye katkı sunmalıdır.

14. Belediyece STK'lara mekân tahsisi yapılabilmelidir. 
15. Belediyelere ait binalarda hizmet veren Aile Hekimlerinden kira alınmayarak onlara destek olunmalıdır. Ayrıca klima, jeneratör ve merkezlerin iç tefrişatı konusunda belediyeler öncü rol oynayarak destek olmalıdır.

16. Belediyeler beldelerinde nüfusun yarısını oluşturan kadınlarımızın sorunlarının çözümü ve şartlarının iyileştirilmesi için "kadın ilişkileri birimi" kurmalıdır. Kadınların ekonomik güç kazanabilmeleri için ekonominin her alanında ve her aşamasında daimî olarak pazar yeri tahsis etmelidir.

17. Belediyeler hiçbir ekonomik geliri olmayan, dolayısıyla hiçbir ekonomik güvencesi olmayan (sağlık, emeklilik) yereldaşlarına yönelik topluca sağlık ve bireysel emeklilik sigortası yapabilmeli ve sosyal belediyeciliğin bu önemli alanını güçlendirmelidir.

18. Belediyeler Zabıta Teşkilatlarını kolluk kuvveti olarak cezalandırıcı yönleriyle değil, iktisadi faaliyetleri adil ve eşitlikçi bir rolle düzenleyici olarak görevlendirmelidir.

19. Belediyeler zorunlu olarak en az 6 ya da 10 spor dalında kulüpleşme yaparak, eğitim tesisi açarak spor faaliyetlerine, ülkemizde sporun gelişimine çok daha ciddi katkılar sunmalıdır.

20. Belediyeler yerel emniyeti sağlamak adına görev yapan emniyet güçleriyle iş birliği yaparak özellikle yereldaşların can ve mal emniyetinin korunmasında, trafik düzenlemesinde emniyet güçleriyle müşterek hareket edebilmelidir. Gece devriyelerine zabita güçleriyle katılabilmelidir.

21. Belediyeye ait bazı yerlerin kullanım hakkı ve ticari işletmesi, bölgede öncü ve önemli konularla ilgilenen STK'lara verilerek onlara destek olunabilir.

22. Belediyeler fosil yakıtlı sanayinin bölgeye gelmemesi konusunda ilgili STK'lara yardımcı olmalıdır. Turizm üzerine yoğunlaşarak, deniz ve ormandan yararlanıp bölgenin turistik bir ilçe olması sağlanmalıdır.

23. Sivil toplum kuruluşları için bir danışma mekanizmasının kurulması gerekiyor. En önemli sorunlardan bir tanesi böyle bir iş birliği içerisinde hem sivil toplum kuruluşlarının hem de kamu kurumlarının nasıl temsil edileceği ve seçileceği, hangi kriterlere göre karar verileceğinin belirlenmesidir.

24. İdare sivil toplum kuruluşlarının faaliyetlerini bardağın boş kısmı olarak değil de dolu kısmı olarak görmelidirler. Yöneticilerin kendini talimat veren diğerlerini emir alan ve uygulayan olarak görme tarzını terk etmesi ve sivil toplum kuruluşlarına gerekli mantığıyla yaklaşması gerekmektedir.

25. Birçok sivil toplum kuruluşu faaliyetlerini yürütmede, organize etmede, plan ve programını oluşturmada yönetsel bilgi ve beceri eksikliği yaşamaktadır. Bu bakımdan sivil toplum kuruluşlarının yöneticilerinin yetiştirilmesine yönelik üniversitelerde bölümler açılmalıdır.

26. Türkiye'de faaliyet gösteren sivil toplum kuruluşları arasında iletişim ve diyalog eksikliği bulunmaktadır. Bu bakımdan toplumsal sorunlarda ortak hareket ve güç birliği kolayca sağlanamamaktadır. Türkiye'deki sivil toplum kuruluşları kendi aralarında iletişim kurmalı, ortak projeler üretmeli ve yardımlaşma, iş birliği ve diyalog gayreti içinde olmalıdır.

27. Kamu ve sivil toplum sektörü içinde karşılıklı güvensizlik çok ciddi boyutlarda, özellikle kamu sektöründe iyi STK, kötü STK, yani bizim gibi düşünen ve düşünmeyen sivil toplum kuruluşu ayrımı yapma eğilimi çok güçlüdür. Sivil toplum kuruluşlarının da kamu ile iş birliği yapmaya çok sıcak bakmadıkları çoğu zaman ve ne olursa olsun projelerin başarısızlıkla sonuçlanacaklarına inandıkları söylenebilir. Bir diğer sorun da iş birliğinin önünde yer alan sivil toplumu temsil eden şemsiye kuruluşların olmamasıdır.

\section{KAYNAKÇA}

Akad, M. (1976). Baskı Gruplarının Siyasal İktidarla İlişkileri, Doktora Tezi, Fakülteler Matbaası, İstanbul. 
Acı Y. Esra (2005). Kalkınma Sürecinin Yeni Aktörleri: Sivil Toplum Kuruluşları, Günizi Yayıncılık, İstanbul.

Akbal, İ. (2017). Sivil Toplum, Sivil Toplum Düşüncesi, Sivil Toplum Kuruluşları ve Kamu Yönetiminde Karar Alma Üzerinde Etkisi, Çizgi Kitapevi.

Ekrem, C., (2012). Türkiye “de Kamu Kurumu Niteliğindeki Meslek Kuruluşlarının Yeniden Yapılandırılmasına İlişkin Reform Önerisi, Proje Koordinatörleri: Atilla Yayla vd. Yılmaz Liberal Düşünce Topluluğu Derneği .

Erdoğan Çağlar, Ş. (2020). Mevcut Anayasa ve Yasalar Çerçevesinde Yerel Yönetimler ile Sivil Toplum Kuruluşları İlişkisinin İncelenmesi: Silivri Örneği, Kitapyurdu Doğrudan Yayıncılık, İstanbul.

Güneş, İ. ve Tekgül B. Y. (2005). Sivil Toplum Kuruluşları ve Yerel Yönetimler, II. Ulusal Sivil Toplum Kuruluşları Kongresi Bildiriler Kitabı, 15-16 Ekim 2005, Çanakkale.

Güneş, İ. (2004). Sivil Toplum Kuruluşları, Son Baskı, Sanal Dergi, 1(2),5.

http://cevre.mf.duzce.edu.tr/

Miller, D., Coleman J. ve Connolly, W. (1995). Blackwell'in Siyasal Düşünce Ansiklopedisi, (Çev: Bülent Peker-Nevzat Kıraç), Ümit Yayını, Ankara.

Mete, T., (1998). Sivil Toplum Kuruluşlarn ile İlgili Kavramlar, Tanzimat'tan Günümüze İstanbul'da STK'lar, Tarih Vakfı Yayınları, İstanbul,

Mevzuat Bilgi Sistemi, 5216 sayılı Büyükşehir Belediyesi Kanunu ve 5393 sayılı Belediye Kanunu, https://www.mevzuat.gov.tr/MevzuatMetin/1.5.5393.pdf, (Erişim Tarihi: 28.12.2019)

Mevzuat Bilgi Sistemi, 5393 sayll Belediye Kanunu, https://www.mevzuat.gov.tr/Metin1.Aspx?MevzuatKod=1.5.5393, (Erişim Tarihi: 28.12.2019)

Mevzuat Bilgi Sistemi Resmi Sayfası, Kent Konseyi Yönetmeliği, https://www.mevzuat.gov.tr/Metin.Aspx?MevzuatKod=7.5.10687\&Mevzuatlliski, （Erişim Tarihi: 28.12.2019)

Mevzuat Bilgi Sistemi Resmi Sayfası, Türk Medeni Kanunu, https://www.mevzuat.gov.tr/MevzuatMetin/1.5.4721.pdf, (Erişim tarihi: 28.12.2019)

Mevzuat Bilgi Sistemi Kakfflar Kanunu, https://www.mevzuat.gov.tr/MevzuatMetin/1.5.5737.pdf, (Erişim tarihi: 28.12.2019)

Mevzuat Bilgi Sistemi Resmi Sayfası, Sendikalar ve Toplu İş Sözleşmesi Kanunu, ,https://www.mevzuat.gov.tr/Metin1.Aspx?MevzuatKod=1.5.6356\&MevzuatIliski (Erişim Tarihi: 28.12.2019)

Hazar, N., Bilgin, N. ve Tanıyıcı, Ş. (1997). Türkiye'de Kooperatifçilik, Türk Kooperatifçilik Kurumu Yayınları, Yayın No: 88, Ankara,

Özdemir, G. ve Başaran, B., (2003). Türkiye "de Kooperatifçiliğin Fikir, Anayasa ve Kalkınma Planları Çerçevesinde İncelenmesi, Üçüncü Sektör Kooperatifçilik Dergisi, 142, 10.

Özkan, Y., (2007). Sivil Toplum Örgütleri, 'Özerklik': Kavramsal Bir Açılım, Gaziantep Üniversitesi Sosyal Bilimler Dergisi, 6, (1), 53-57.

Özden, K. ve Zorlu, M., (2010). Yerel Yönetimlerde Açılım: 1580 sayılı Belediye Kanunu ile 5393 sayılı Belediye Kanunun Arasındaki Farklar, Yerel Siyaset Dergisi, 4(36),13.

Ökmen, M. ve Parlak, B., (2010). Kuramdan Uygulamaya Yerel Yönetimler - İlkeler, Yaklaşımlar ve Mevzuat, Alfa Aktüel. 
Sivil Toplumla İlişkiler Genel Müdürlüğü Resmi Sayfası, 1982 Anayasası, https://www.siviltoplum.gov.tr/anayasa, (Erişim Tarihi: 28.12.2019)

Terlikçi, M., (2020). Silivri Belediyesi Kültür ve Sosyal İşler Müdürlüğü, Yapılan Röportaj.

Türkiye Büyük Millet Meclisi Resmi Sayfası, T.C. 1982 Anayasası, https://www.tbmm.gov.tr/anayasa/anayasa_2018.pdf (Erişim Tarihi: 28.12.2019)

Tosun, G., (2004). Türkiye'de Devlet-Sivil Toplum İlişkisi ve Demokrasinin Pekişmesinin Önündeki Engeller, Sivil Toplum: Farklı Bakışlar, Kaktüs Yayınları, İstanbul.

Tekeli, İ., (2002). Sivil Toplum Kuruluşları, Yerelleşme ve Yerel Yönetimler, Türkiye Ekonomik ve Toplumsal Tarih Vakfı Yayını, İTÜ Maçka Sosyal Tesisleri, 